\title{
CHEMICAL AND MICROBIOLOGICAL ATTRIBUTES OF AN OXISOL TREATED WITH SUCCESSIVE APPLICATIONS OF SEWAGE SLUDGE ${ }^{(1)}$
}

\author{
José Rafael Pires Bueno(2), Ronaldo Severiano Berton ${ }^{(3)}$, Adriana \\ Parada Dias da Silveira ${ }^{(3)}$, Marcio Koiti Chiba ${ }^{(3)}$, Cristiano Alberto \\ de Andrade ${ }^{(4)} \&$ Isabella Clerici De Maria ${ }^{(3)}$
}

\begin{abstract}
SUMMARY
Studies on sewage sludge (SS) have confirmed the possibilities of using this waste as fertilizer and/or soil conditioner in crop production areas. Despite restrictions with regard to the levels of potentially toxic elements (PTE) and pathogens, it is believed that properly treated SS with low PTE levels, applied to soil at adequate rates, may improve the soil chemical and microbiological properties. This study consisted of a long-term field experiment conducted on a Typic Haplorthox (eutroferric Red Latosol) treated with SS for seven successive years for maize production, to evaluate changes in the soil chemical and microbiological properties. The treatments consisted of two SS rates (single and double dose of the crop $\mathrm{N}$ requirement) and a mineral fertilizer treatment. Soil was sampled in the 0-0.20 m layer and analyzed for chemical properties (organic $\mathrm{C}, \mathrm{pH}, \mathrm{P}, \mathrm{K}, \mathrm{Ca}$, $\mathrm{Mg}, \mathrm{CEC}, \mathrm{B}, \mathrm{Cu}, \mathrm{Fe}, \mathrm{Mn}, \mathrm{Zn}, \mathrm{Cd}, \mathrm{Ni}$, and $\mathrm{Pb}$ ) and microbiological properties (basal respiration, microbial biomass activity, microbial biomass $\mathrm{C}$, metabolic quotient, microbial quotient, and protease and dehydrogenase enzyme activities). Successive SS applications to soil increased the macro- and micronutrient availability, but the highest SS dose reduced the soil $\mathrm{pH}$ significantly, indicating a need for periodic corrections. The SS treatments also affected soil microbial activity and biomass negatively. There were no significant differences among treatments for maize grain yield. After seven annual applications of the recommended sludge rate, the heavy metal levels in the soil had not reached toxic levels.
\end{abstract}

Index terms: municipal waste, organic matter, soil microbes, maize.

(1) Paper extratecd from the Master Dissertation of the first author. Received for publication in September 28, 2010 and approved in May 24, 2011.

${ }^{(2)}$ Master in Agricultura Tropical e Subtropical Program of Instituto Agronômico, Caixa Postal 28, CEP 13001-970 Campinas (SP). CAPES scholarship holder. E-mail: zekapiresbueno@gmail.com

(3) Scientific researcher of Centro de Solos e Recursos Ambientais, Instituto Agronômico. E-mails: berton@iac.sp.gov.br; apdsil@iac.sp.gov.br; mkchiba@iac.sp.gov.br; icdmaria@iac.sp.gov.br

(4) Scientific researcher of Embrapa Meio Ambiente, Caixa Postal 69, CEP 13820-000 Jaguariúna (SP). E-mail: andrade@cnpma.embrapa.br 


\title{
RESUMO: ATRIBUTOS QUÍMICOS E MICROBIOLÓGICOS DE UM LATOSSOLO TRATADO COM APLICAÇÕES SUCESSIVAS DE LODODE ESGOTO
}

\begin{abstract}
Estudos realizados com lodo de esgoto (LE) têm demonstrado o potencial desse resíduo como fertilizante e, ou, condicionador do solo em áreas agrícolas. Apesar das restrições quanto ao conteúdo de elementos potencialmente tóxicos (EPT), como os metais pesados, e de patógenos, a aplicação de LE com baixos teores de EPT e devidamente higienizado poderá melhorar os atributos químicos e microbiológicos do solo. Em um Latossolo Vermelho com caráter férrico cultivado com milho, avaliaram-se as alterações nos atributos químicos e microbiológicos do solo em dois tratamentos com LE aplicado sucessivamente por sete anos: na dose recomendada para suprir o $N$ requerido pela cultura do milho e no dobro da dose recomendada, bem como em um tratamento com adubação mineral. Foram coletadas amostras compostas de solo, na profundidade de 0-0,20 m, para determinação de atributos químicos ( $C$-orgânico, $p H, P, K$, $\mathrm{Ca}, \mathrm{Mg}, \mathrm{CTC}, \mathrm{B}, \mathrm{Cu}, \mathrm{Fe}, \mathrm{Mn}, \mathrm{Zn}, \mathrm{Cd}$, Ni e Pb) e microbiológicos (respiração basal, atividade microbiana, $C$ da biomassa microbiana, quociente metabólico, quociente microbiano $e$ atividade das enzimas protease e desidrogenase). A adição sucessiva de LE ao solo aumentou a disponibilidade de macro e micronutrientes para as culturas. Entretanto, na maior dose do $L E$ houve redução significativa do $\mathrm{pH}$, indicando a necessidade de correções periódicas da acidez do solo. A adição do LE causou efeito negativo sobre a atividade e biomassa da microbiota do solo. Não houve diferença significativa para a produção de grãos de milho entre os tratamentos. Após sete aplicações anuais de LE baseadas na necessidade do milho em N, os níveis de metais pesados no solo não atingiram níveis tóxicos.
\end{abstract}

Termos de indexação: resíduos urbanos, matéria orgânica, microbiota do solo, milho.

\section{INTRODUCTION}

The fast development of metropolitan regions generates ever- increasing amounts of all sorts of residues. Among these, sewage sludge (SS) has been studied as a possible nutrient source for crops in agricultural areas. The proposal of using SS in crop fields as a sustainable way of SS disposal is based on the high organic $\mathrm{C}$ and nutrient levels.

A typical SS usually contains around $40 \%$ organic matter, $4 \% \mathrm{~N}, 2 \% \mathrm{P}$ and lower amounts of other nutrients (Bettiol \& Camargo, 2006). Sewage sludge has been used as organic fertilizer at rates equivalent to its NPK contents, such as the commercial fertilizer formula 4: 2.5: 1 (N: P: K). Also, this organic residue has been recommended as soil conditioner, since it increases soil water retention capacity, porosity and aggregate stability, due to its high organic matter content (Jorge et al., 1991).

Nevertheless, the fact that potentially toxic elements may be present in SS residues requires constant monitoring of the SS composition, prior to application to agricultural soils, to ensure the preservation of the environmental quality. This is particularly relevant because some toxic elements such as heavy metals may persist indefinitely in the soil and alter the environment quality. This means that plants can absorb toxic elements in quantities high enough to damage not only crop plants but also the health of animals and/or humans and to contaminate the entire food chain (Berton, 2000).
In Brazil, the few studies in the literature that describe the effects of long-term successive SS field applications on soil chemical, physical and biological properties, are generally positive reports. Fernandes et al. (2005) evaluated the effects of two SS types on soil microbiological properties after four years of successive applications and found a significant increase in microbial activity related to the applied SS rates. Nogueira et al. (2008) studied soil treated with SS for nine years and found similar maize dry matter and grain yield as on chemically fertilized plots. Also, these authors found that among the investigated heavy metals, only the Zn contents increased in the soil, as a consequence of SS application. De Maria et al. (2010) observed lower soil density, greater porosity and improved soil physical quality after six successive SS applications.

Nevertheless, the results may vary not only according to the SS quantity applied to the soil but also to the SS type, which depends on the residue origin and treatment method.

The purpose of this study was to quantify the accumulated effects of seven successive annual SS (unlimed) applications on chemical and microbiological soil properties, and also to determine whether the SS rate calculated according to the maize $\mathrm{N}$ demand improves soil fertility and stimulates microbial activity and if the maize yield remains stable even without additional mineral fertilizer (N-P) and excessive accumulation of potentially toxic elements. 


\section{MATERIALS AND METHODS}

The experiment was carried out at the experimental station of the Instituto Agronômico Campinas, State of São Paulo, Brazil (22 52 ’ $44^{\prime}$ S, $47^{\circ} 04^{\prime} 56$ ” W; $650 \mathrm{~m}$ asl). The soil was classified as a clayey eutroferric Red Latosol, according to the Brazilian System of Soil Classification (Embrapa, 2006), somewhat similar to Typic Haplorthox (USDA) and Rhodic Ferrasol (FAO). The climate was defined as a humid tropical with a clearly defined rainy summer and dry winter, with an average rainfall of $1,400 \mathrm{~mm}_{\text {year }}^{-1}$ and average annual temperature of $20.5^{\circ} \mathrm{C}$.

The experiment was arranged in a randomized complete block design with three treatments and four replications. The slope of the 4 x $25 \mathrm{~m}$ plots had $10 \%$ declivity and the treatments consisted of two sewage sludge (SS) rates (L1 and L2) and a single annual mineral fertilizer rate (as control treatment), applied from 2001 to 2007.

The SS used in the experiment came from the municipal Wastewater Treatment Plant of the city of Jundiaí, State of São Paulo. This domestic waste sludge is treated biologically and aerobically in complete-mix aerated lagoons and then a settling pond for solids removal. The process is continued by centrifugation and dewatering for 120 days, using a mechanical rotator. The pathogen concentration in this residue was classified as B and there are no restrictions to agricultural use with regard to the heavy metal concentrations, according to the Brazilian law (directive P 4230, CETESB, 1999). The chemical characteristics of the sewage sludge used in this longterm experiment are presented in table 1.

The SS rates (L1 and L2) were calculated in the first year of the experiment, based on maize $\mathrm{N}$ demand. Thus, according to the directive P 4230 (CETESB, 1999) the recommended SS rate was calculated by equation 1 :

$$
\begin{gathered}
\mathrm{SS} \text { application rate }\left(\mathrm{t} \mathrm{ha}^{-1}\right)=\mathrm{N} \text { recommended } \\
\text { rate }\left(\mathrm{kg} \mathrm{ha}^{-1}\right) / \mathrm{SS} \text { available } \mathrm{N}\left(\mathrm{kg} \mathrm{t}^{-1}\right)
\end{gathered}
$$

where, the recommended $\mathrm{N}$ quantity for maize is $80 \mathrm{~kg} \mathrm{ha}{ }^{-1}$, according to Raij et al. (1996); and the SS available $\mathrm{N}$ was calculated by equation 2 , considering a surface application followed by incorporation:

Table 1. Chemical composition of the sewage sludge applied in a Red Latosol cultivated for maize cultivation

\begin{tabular}{|c|c|c|c|c|c|c|c|}
\hline \multirow{2}{*}{ Parameter ${ }^{(1,2)}$} & \multicolumn{7}{|c|}{ Year } \\
\hline & 2001 & 2002 & 2003 & 2004 & 2005 & 2006 & 2007 \\
\hline $\mathrm{pH}$ & 6.6 & 7.2 & - & 7 & - & 6.8 & 5.4 \\
\hline Moisture (\%) & 68.2 & 65.7 & - & 73.4 & - & 65.6 & 67.2 \\
\hline Volatile solids (\%) & 54.8 & 57.3 & 51.2 & 62.3 & 57.9 & 58.9 & 56.3 \\
\hline Organic - C ( $\left.\mathrm{g} \mathrm{kg}^{-1}\right)$ & 325 & 298 & 225 & 288 & 292 & 214 & 313 \\
\hline Nitrogen - total N (Kjeldahl, $\mathrm{g} \mathrm{kg}^{-1}$ ) & 28.3 & 27 & - & 28.9 & 31 & 32.1 & 28.6 \\
\hline Ammonium - N $\left(\mathrm{mg} \mathrm{kg}^{-1}\right)$ & 577 & 438 & - & 266 & - & 287 & 289 \\
\hline Nitrate - nitrite $\mathrm{N}\left(\mathrm{mg} \mathrm{kg}^{-1}\right)$ & 37.2 & 138.7 & - & 2.3 & - & 33.4 & 30.6 \\
\hline Aluminum - $\mathrm{Al}\left(\mathrm{g} \mathrm{kg}^{-1}\right)$ & 16.4 & 18.8 & 19.5 & 23.3 & 18.14 & 21.3 & 18.6 \\
\hline Arsenium - As $\left(\mathrm{mg} \mathrm{kg}^{-1}\right)$ & $<0.01$ & $<0.01$ & $<0.01$ & $<0.01$ & $<0.5$ & $<0.01$ & $<0.5$ \\
\hline Boron - B (mg kg) & 12.3 & 11.7 & 4.3 & 12.7 & 19.8 & 77.8 & 31.3 \\
\hline Cadmium - Cd $\left(\mathrm{mg} \mathrm{kg}^{-1}\right)$ & 5.8 & 6.6 & 6.4 & 13.5 & 12.5 & 9.4 & 3.9 \\
\hline Calcium - $\mathrm{Ca}\left(\mathrm{g} \mathrm{kg}^{-1}\right)$ & 12.3 & 9.8 & 8.09 & 7.32 & 38.2 & 18.3 & 9.2 \\
\hline Lead - $\mathrm{Pb}\left(\mathrm{mg} \mathrm{kg}^{-1}\right)$ & 283 & 207 & 134 & 100 & 157 & 129 & 183 \\
\hline Copper - Cu (mg kg $\left.{ }^{-1}\right)$ & 284 & 865 & 576 & 872 & 540 & 237 & 304 \\
\hline Chromium - Cr $\left(\mathrm{mg} \mathrm{kg}^{-1}\right)$ & 149 & 188 & 153 & $<0.01$ & 150 & 166 & 200 \\
\hline Sulfur $-\mathrm{S}\left(\mathrm{g} \mathrm{kg}^{-1}\right)$ & 26.1 & 26.8 & 25.6 & 12.1 & 14.5 & 16.3 & 18 \\
\hline Iron - Fe $\left(\mathrm{g} \mathrm{kg}^{-1}\right)$ & 26 & 24.1 & 21.3 & 17.2 & 23.3 & 22.3 & 21.9 \\
\hline Phosphorus - P ( $\left.\mathrm{g} \mathrm{kg}^{-1}\right)$ & 6.6 & 7.2 & 5.6 & 13 & 6.3 & 10.7 & 7.1 \\
\hline Magnesium - $\mathrm{Mg}\left(\mathrm{g} \mathrm{kg}^{-1}\right)$ & 2.1 & 1.7 & 1.4 & 1.6 & 1.7 & 1.6 & 1.5 \\
\hline Manganese - Mn $\left(\mathrm{mg} \mathrm{kg}^{-1}\right)$ & 677 & 693 & 476 & 441 & 560 & 648 & 749 \\
\hline Mercury - $\mathrm{Hg}\left(\mathrm{mg} \mathrm{kg}^{-1}\right)$ & $<0.01$ & $<0.01$ & $<0.01$ & $<0.01$ & $<1.0$ & $<0.01$ & $<0.5$ \\
\hline Molybdenum - Mo $\left(\mathrm{mg} \mathrm{kg}^{-1}\right)$ & $<0.01$ & $<0.01$ & $<0.01$ & $<0.01$ & 7.5 & 11.3 & 6.1 \\
\hline Nickel - Ni $\left(\mathrm{mg} \mathrm{kg}^{-1}\right)$ & 41.8 & 35.5 & 37.4 & 35.4 & 29.5 & 42.7 & 189 \\
\hline Selenium - Se $\left(\mathrm{mg} \mathrm{kg}^{-1}\right)$ & $<0.01$ & $<0.01$ & $<0.01$ & - & $<1.0$ & $<0.01$ & $<0.5$ \\
\hline Zinc $-\mathrm{Zn}\left(\mathrm{mg} \mathrm{kg}^{-1}\right)$ & 1365 & 1738 & 1295 & 941 & 1039 & 1551 & 1450 \\
\hline Potassium - K $\left(\mathrm{mg} \mathrm{kg}^{-1}\right)$ & 1500 & 1000 & 826 & 11470 & 967 & 932 & 1074 \\
\hline Sodium - $\mathrm{Na}\left(\mathrm{mg} \mathrm{kg}^{-1}\right)$ & 900 & 1700 & 943 & 8102 & 1138 & 1282 & 1385 \\
\hline Barium - $\mathrm{Ba}\left(\mathrm{mg} \mathrm{kg}^{-1}\right)$ & - & - & - & - & - & 235 & 460 \\
\hline
\end{tabular}
during the period of 2001-2007

\footnotetext{
(1) Ammonium and nitrate $\mathrm{N}$ were analyzed on wet samples by digestion with dichromate and determined by colorimetry. Metals were analyzed according to recommendations of US-EPA, SW-846 and method 3051. Sodium (Na) and potassium (K) were determined by flame photometry and the other elements by ICP-AES. SS moisture and volatile solids were determined by mass loss at 60 and $500{ }^{\circ} \mathrm{C}$, respectively. SS pH was determined in water extract (1:5). ${ }^{(2)}$ The concentration values were calculated on a dry matter basis.
} 


$$
\begin{gathered}
\text { SS available } \mathrm{N}=(\mathrm{MF} / 100) \times\left(\mathrm{N}_{\mathrm{Kj}}-\mathrm{N}_{\mathrm{NH}_{3}}\right)+ \\
\mathrm{N}_{\mathrm{NH}_{3}}+\left(\mathrm{N}_{\mathrm{NO}_{3}}^{-}+\mathrm{N}_{\mathrm{NO}_{2}}^{-}\right)
\end{gathered}
$$

where $\mathrm{N}_{\mathrm{Kj}}=$ total nitrogen (Kjeldahl) in $\mathrm{mg} \mathrm{kg}^{-1} ; \mathrm{N}_{\mathrm{NH}_{3}}$ = ammonium-nitrogen in $\mathrm{mg} \mathrm{kg}^{-1} ; \mathrm{N}_{\mathrm{NO}_{3}}=$ nitratenitrogen in $\mathrm{mg} \mathrm{kg}^{-1} ; \mathrm{N}_{\mathrm{NO}_{2}}{ }^{-}=$nitrite-nitrogen in $\mathrm{mg} \mathrm{kg}^{-1}$; $\mathrm{MF}=$ mineralization fraction, determined in a laboratory incubation test.

Based on this equation, the available $\mathrm{N}$ was around $1 / 3$ of the total $\mathrm{N}\left(8 \mathrm{~kg} \mathrm{t}^{-1}\right)$ in the SS; consequently, the recommended SS rate (L1) was $10 \mathrm{t} \mathrm{ha}^{-1}$ year-1 $^{-1}$ and L2, twice as much $\left(20 \mathrm{t} \mathrm{ha}^{-1}\right.$ year $\left.^{-1}\right)$, on a dry matter basis. The control treatment consisted of SSfree mineral fertilizer (MF) at the recommended rate (equivalent to L1) for comparison $\left(80 \mathrm{~kg} \mathrm{ha}^{-1} \mathrm{~N}\right.$ ).

The mineral fertilizer (MF) treatment consisted of $\mathrm{N}\left(6 \mathrm{~kg} \mathrm{ha}^{-1}\right), \mathrm{P}_{2} \mathrm{O}_{5}\left(21 \mathrm{~kg} \mathrm{ha}^{-1}\right)$ and $\mathrm{K}_{2} \mathrm{O}\left(12 \mathrm{~kg} \mathrm{ha}^{-1}\right)$ at sowing and $\mathrm{N}$ side dressing $\left(75 \mathrm{~kg} \mathrm{ha}^{-1}\right)$. Treatments (L1 and L2) with sewage sludge were complemented with mineral $\mathrm{K}$ fertilizer at the same rate as in the $\mathrm{MF}$ treatment $\left(12 \mathrm{~kg} \mathrm{ha}^{-1} \mathrm{~K}_{2} \mathrm{O}\right)$, at each sowing.

The plant residues on all experimental plots were incorporated into the soil. Sewage sludge was also manually applied and hoed into the soil to a depth of $10 \mathrm{~cm}$. Maize was grown on the plots in the summer (0.90 $\mathrm{m}$ between rows and five plants per meter). In fall and winter, the soil was left fallow with plant residues on the surface.

In November 2008, the $0-20 \mathrm{~cm}$ soil layer was sampled using a hand auger. Each composite soil sample was represented by 15 subsamples. The composite soil samples were homogenized, air dried, passed through a $2 \mathrm{~mm}$ sieve and submitted to chemical analyses, as described by Raij et al. (2001): $\mathrm{pH}$ in $0.01 \mathrm{~mol} \mathrm{~L}^{-1} \mathrm{CaCl}_{2}$ solution; organic $\mathrm{C}$ by humid digestion and colorimetric determination; $\mathrm{P}, \mathrm{K}, \mathrm{Ca}$, and $\mathrm{Mg}$ by ion exchange resin extraction and determination by colorimetry $(\mathrm{P})$ and flame photometry (K, $\mathrm{Ca}$ and $\mathrm{Mg}$ ); potential acidity by the SMP buffer solution method; $\mathrm{S}$ by extraction with $0.01 \mathrm{~mol} \mathrm{~L}^{-1} \mathrm{Ca}\left(\mathrm{H}_{2} \mathrm{PO}_{4}\right)$ solution and determination by spectrophotometry; $\mathrm{B}$ by hot water extraction and colorimetric determination; $\mathrm{Cu}, \mathrm{Fe}, \mathrm{Mn}, \mathrm{Zn} \mathrm{Cd}, \mathrm{Pb}$, $\mathrm{Ni}$, and $\mathrm{Cr}$ by extraction with DTPA (pH 7.3) solution and determination by atomic absorption spectrometry.

An aliquot sample of the original soil sample (before air-drying) was cooled $\left(5^{\circ} \mathrm{C}\right)$ for the microbiological analyses. Basal respiration (BR) was measured as follows: $100 \mathrm{~g}$ soil was moistened to $60 \%$ of the maximal water retention capacity and incubated at $25-30{ }^{\circ} \mathrm{C}$ for 5 days in the dark. The released $\mathrm{CO}_{2}$ was captured in $10 \mathrm{~mL}$ of $0.01 \mathrm{~mol} \mathrm{~L}^{-1} \mathrm{NaOH}$ solution, to which $1 \mathrm{~mL}$ of $\mathrm{BaCl}_{2}(50 \% \mathrm{~m} / \mathrm{v})$ was added, plus 2 drops of phenolphthalein and titrated with $0.1 \mathrm{~mol} \mathrm{~L}^{-1}$ $\mathrm{HCl}$ solution.

Microbial activity (MBA) was measured according to the method suggested by Werf \& Vestrate (1987), modified as follows: before the beginning of the second sample incubation period, the sample was incubated for $10 \mathrm{~h}$ with $120 \mathrm{mg}$ glucose, $30 \mathrm{mg}$ yeast extract, $45 \mathrm{mg} \mathrm{NH} \mathrm{Nl}_{4} \mathrm{Cl}, 12 \mathrm{mg} \mathrm{MgSO}_{4} \cdot 7 \mathrm{H}_{2} \mathrm{O}$ and $10 \mathrm{mg}$ $\mathrm{KH}_{2} \mathrm{PO}_{4}$ and titrated with $0.01 \mathrm{~mol} \mathrm{~L}^{-1} \mathrm{HCl}$ solution, as reported by Islam (2000). The data were multiplied by a coefficient (0.283) convert the "respired C" into microbial activity. Microbial biomass C (MBC) was determined by the method of fumigation-extraction (Vance et al., 1987). The metabolic quotient $\left(q \mathrm{CO}_{2}\right)$ was obtained by the $\mathrm{MBC} / \mathrm{BR}$ ratio and indicates the efficiency of the microbial community to incorporate C into its own biomass (Anderson \& Domsh, 1989). The microbial quotient (Qmic) was obtained by the MBA/org-C ratio (Tótola \& Chaer, 2002). The protease enzyme activity was determined using the method described by Ladd \& Butler (1972) and the dehydrogenase activity (DHA) according to Casida et al. (1964).

The data were subjected to analysis of variance by the $\mathrm{F}$ test and treatment means were compared by the Tukey test $(\mathrm{p}<0.05)$.

\section{RESULTS AND DISCUSSION}

Samples of the sewage sludge (SS) used during the long-term experiment were analyzed and the data used to estimate the total amounts of chemical elements applied to the soil, considering both SS rates 10 and $20 \mathrm{tha}^{-1}$ (Table 2). The main SS contribution to soil fertility was related to $\mathrm{C}$ addition, calculated to be around $20 \mathrm{t} \mathrm{ha}^{-1}$ after seven years in the L1 treatment. Soil macronutrient accumulation was ranked in the following decreasing order: $\mathrm{Ca}>\mathrm{P}>\mathrm{K}>\mathrm{Mg}$.

The $\mathrm{P} / \mathrm{K}$ ratios (5:1) of sewage sludge were well above the recommended ratio (1.5:1) for maize in Oxisols, according to Raij et al. (1996). These high P/ $\mathrm{K}$ ratios evidenced the need for $\mathrm{K}$ complementation in fields fertilized with SS, to supply enough K to maize and N:P:K in adequate proportions, as proposed by Pratt et al. (1977) and confirmed by Simonete et al. (2003) under greenhouse conditions. In this experiment, the plots with sewage sludge were complemented with mineral $\mathrm{K}$, as previously described.

Calcium and $\mathrm{Mg}$ quantities added by SS rates reached ratios of up to 10:1 and indicated the need for monitoring soil Mg concentrations. According to Souza et al. (2007), adequate $\mathrm{Ca} / \mathrm{Mg}$ ratios can vary according to crop and soil, but should usually be around 3:1 or 4:1 (molar ratio). Muñoz Hernandez \& Silveira (1998) observed that Ca:Mg ratios > 3:1 caused a decrease in maize growth and grain yield, due to the antagonistic effect of Ca on $\mathrm{Mg}$ uptake by plants. Obviously, these nutrient ratios must be evaluated, based on the available rather than the total element concentrations in the soil, once the ratios based on the latter are not relevant. Over the course of time, the amounts of S 
Table 2. Total amount of chemical elements disposed in the soil by the sewage sludge rates of 10 and $20 \mathrm{t} \mathrm{ha}^{-1}$ year $^{-1}$, respectively $\mathrm{L} 1$ and $\mathrm{L} 2$, during the period of 2001-2007

\begin{tabular}{|c|c|c|}
\hline Element & L1 & L2 \\
\hline & \multicolumn{2}{|c|}{$-\mathrm{kg} \mathrm{ha}^{-1(1)}$} \\
\hline Organic - C & 19550 & 39100 \\
\hline Nitrogen - N (Kjeldahl) & 1759 & 3518 \\
\hline Iron & 1561 & 3122 \\
\hline Sulfur & 1394 & 2788 \\
\hline Aluminum & 1360 & 2721 \\
\hline Calcium & 1032 & 2064 \\
\hline Phosphorus & 565 & 1130 \\
\hline Potassium & 178 & 355 \\
\hline Sodium & 155 & 309 \\
\hline Magnesium & 116 & 232 \\
\hline Zinc & 94 & 188 \\
\hline Manganese & 42 & 85 \\
\hline Copper & 37 & 74 \\
\hline Ammonium - N & 19 & 37 \\
\hline Lead & 12 & 24 \\
\hline Chromium & 10 & 20 \\
\hline Barium & 7 & 14 \\
\hline Nickel & 4 & 8 \\
\hline Nitrate - nitrite - N & 2 & 5 \\
\hline Boron & 2 & 3 \\
\hline Cadmium & 1 & 1 \\
\hline Molybdenum & 0.25 & 0.50 \\
\hline Arsenium & $\mathrm{ND}^{(2)}$ & ND \\
\hline Mercury & ND & ND \\
\hline Selenium & ND & ND \\
\hline
\end{tabular}

(1) On a dry matter basis. ${ }^{(2)}$ ND: not determined, due to the low concentration in the original residue which was below the detection limit by the analytical method used.

applied to the soil also became significant, which is an important aspect, since usually no specific S source is included in commercial fertilizers for commercial crops.

The soil organic $\mathrm{C}$ concentration was significantly higher in the SS-treated than in the chemically fertilized (MF) plots (Table 3). This result was expected, since the $\mathrm{SS}$ is a high org-C content residue. Soil org-C increased $23.8 \%$ in SS-treated plots (10 t ha-1) compared to MF-plot, corroborating results reported by Melo et al. (1994), Oliveira (2000), Melo et al. (2004) and Chiba et al. (2008). These authors observed increasing soil org-C contents with the increasing sewage sludge rates applied.

Similarly, the L1 and L2 SS rates induced increases in soil $\mathrm{P}$ concentrations (resin extract, available P) of 120 and $240 \%$, respectively, compared to the MF-treatment. Similar increases in soil available $\mathrm{P}$ were reported by Berton et al. (1989), in SS-treated soils growing maize in a greenhouse and by Simonete (2003), in a field experiment. Chiba et al. (2009) pointed out that SS contributes significantly to the $\mathrm{P}$ crop supply. These authors reported that $30 \%$ of the sugarcane $\mathrm{P}$ demand was supplied by SS applied to the soil.
It is important to emphasize the high $\mathrm{P}$ application to soil during this long-term experiment to explain the increase in $\mathrm{P}$ availability in the SS-treated plots, calculated as around 565 and $1,130 \mathrm{~kg} \mathrm{ha}^{-1}$ of total P in the SS applications, corresponding to 80.71 and $161.43 \mathrm{~kg} \mathrm{ha}^{-1}$ year $^{-1}$ against $21 \mathrm{~kg} \mathrm{ha}^{-1} \mathrm{P}$ in the MFtreatment. The higher soil available $P$ contents found in the SS plots may be attributed to: (a) the presence of water-soluble P in the SS (Berton \& Pratt, 1997); (b) mineralization of org-P present in the soil after SS application (Sattel \& Morris, 1992); (c) organic acid release from SS decomposition and subsequent reaction with $\mathrm{P}$ in soil solution, resulting in $\mathrm{P}$-organic acid complex molecules; this reaction would prevent precipitation of soluble-P as well as block the adsorption site for $\mathrm{P}$ in the solid phase, thus decreasing the soil adsorption capacity for P (Nagajarah et al., 1970); and (d) the higher soil CEC values observed in SS-treated plots might also have contributed to increase the repulsion charges between phosphate anion and the adsorbent surface, thus decreasing the electrostatic potential of the anionic adsorption surface (Barrow, 1985). It is highlighted that the increase in soil-available P concentrations occurred after seven annual SS applications, with simultaneous $\mathrm{pH}$ decrease, which may also have induced $\mathrm{Fe}-\mathrm{P}$ and $\mathrm{Al}-$ $\mathrm{P}$ solubilization. During the first two years of this field experiment, the available $\mathrm{P}$ concentrations in SS-treated soils were similar to those found in MFtreated plots (Galdos et al., 2004).

The significant $\mathrm{pH}$ reduction observed in SS-treated plots (Table 3) was followed by a significant reduction in the soil-available $\mathrm{Ca}$ and $\mathrm{Mg}$ concentrations and increased potential acidity $(\mathrm{H}+\mathrm{Al})$. According to Raij et al. (1996), the soil acidity values in the MF plots can be classified as medium ( $\mathrm{pH} 5.1$ to 5.5) for field crops, but the values in the SS-treated plots were classified as high ( $\mathrm{pH}$ 4.4-5.0, L1 treatment) and very high ( $\mathrm{pH}<4.4$, $\mathrm{L} 2$ treatment).

SS application to agricultural areas can increase or decrease soil acidity, depending on the type of SS treatment in the Wastewater Treatment Plants (WTP). SS treated with hydrated calcium oxide during the disinfection or coagulation process is an alkaline residue that increases soil $\mathrm{pH}$, as observed by Berton et al. (1989).

The soil $\mathrm{pH}$ decrease observed in the SS-treated plots might also be due to the $\mathrm{H}^{+}$release during org$\mathrm{N}$ mineralization from organic residues and to the increment of soil org-C added by SS applications, also causing $\mathrm{pH}$ decreases as well. Thus, the decreased $\mathrm{pH}$ values observed in this study might be attributed to the type and composition of sewage sludge used, which specifically was only centrifuged with polyelectrolytes and not treated with hydrated $\mathrm{CaO}$.

At low $\mathrm{pH}$ values, SS-treated soils tend to have a higher availability of most heavy metals, i.e., SS applications must be monitored to prevent food chain 
Table 3. Soil chemical attributes at 0-0.20 $\mathrm{m}$ depth layer after addition of sewage sludge (SS) (L1 $=10 \mathrm{t} \mathrm{ha} \mathrm{h}^{-1}$ and $\mathrm{L2}=20 \mathrm{t} \mathrm{ha}^{-1}$ ) and mineral fertilizer treatments

\begin{tabular}{|c|c|c|c|c|c|c|c|c|c|}
\hline Treatment & Org-C & pH & P-res & $\mathbf{K}^{+}$ & $\mathrm{Ca}^{2+}$ & $\mathrm{Mg}^{2+}$ & $\mathbf{H}+\mathbf{A l}$ & CEC & V \\
\hline & $\mathrm{g} \mathrm{kg}^{-1}$ & & $\mathrm{mg} \mathrm{dm}^{-3}$ & & 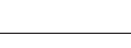 & $\mathrm{mmol}_{\mathrm{c}} \mathrm{dm}$ & & & $\%$ \\
\hline L2 & $17.74 \mathrm{~A}$ & $3.9 \mathrm{C}$ & $52.75 \mathrm{~A}$ & $1.48 \mathrm{~B}$ & $8.50 \mathrm{~B}$ & $2.25 \mathrm{C}$ & $109.75 \mathrm{~A}$ & $122.20 \mathrm{~A}$ & $10.25 \mathrm{C}$ \\
\hline L1 & $15.75 \mathrm{~A}$ & $4.6 \mathrm{~B}$ & $39.00 \mathrm{~B}$ & $2.05 \mathrm{AB}$ & $19.25 \mathrm{~A}$ & $7.25 \mathrm{~B}$ & $52.25 \mathrm{~B}$ & $80.90 \mathrm{~B}$ & $35.25 \mathrm{~B}$ \\
\hline MF & $12.72 \mathrm{~B}$ & $5.3 \mathrm{~A}$ & $25.50 \mathrm{C}$ & $2.68 \mathrm{~A}$ & $25.50 \mathrm{~A}$ & $14.50 \mathrm{~A}$ & $28.00 \mathrm{C}$ & $70.53 \mathrm{~B}$ & $60.25 \mathrm{~A}$ \\
\hline CV (\%) & 12.15 & 3.39 & 12.88 & 14.03 & 17.59 & 23.84 & 14.43 & 9.41 & 9.88 \\
\hline $\mathrm{F}$ test & 0.0246 & 0.0001 & 0.0008 & 0.0030 & 0.0007 & 0.0003 & 0.0001 & 0.0003 & 0.0001 \\
\hline
\end{tabular}

Means followed by the same letter in the same column do not differ by Tukey test $(p<0.05)$.

contamination. Berton et al. (1997) does not recommend residue applications containing high amounts of $\mathrm{Cu}, \mathrm{Cd}, \mathrm{Ni}$ and $\mathrm{Zn}$ to the soil, at soil $\mathrm{pH}<5.3$.

In relation to micronutrients, higher soil concentrations were observed in SS-treated plots (Mn $>\mathrm{Fe}>\mathrm{Zn}>\mathrm{Cu}>>\mathrm{B}$, Table 4). SS application increased the availability of these elements in comparison to MF treatment. Despite the $200 \%$ increase in soil Cu-DTPA concentrations observed in SS-treated plots, and the fact that these values were well above the level considered high for agricultural areas (> $0.8 \mathrm{mg} \mathrm{dm}^{-3}$, according to Raij et al., 1996), the available $\mathrm{Cu}$ concentrations were below the toxicity limit for plants $\left(20 \mathrm{mg} \mathrm{dm}^{-3}\right.$ ) established by Malavolta (2006). Similar results were found for the available concentrations of $\mathrm{Mn}, \mathrm{Zn}$ and Fe (Table 4).

Increased soil basal respiration (BR) was observed with the SS rates, reaching 36 and $78 \%$ higher values in SS than in MF plots, with $\mathrm{L} 1$ and $\mathrm{L} 2$ rates, respectively (Table 5). This confirmed results reported by Cardoso \& Fortes Neto (2000) and Fernandes et al. (2005). Positive correlations were observed between $\mathrm{BR}$ values and the soil concentration increases of $\mathrm{P}(\mathrm{r}$ $=0.65 ; \mathrm{p} \leq 0.02), \mathrm{B}(\mathrm{r}=0.59 ; \mathrm{p} \leq 0.04) ; \mathrm{Fe}(\mathrm{r}=0.55$; $\mathrm{p} \leq 0.05)$ and $\mathrm{CEC}(\mathrm{r}=0.74 ; \mathrm{p} \leq 0.006)$, as a consequence of the SS chemical composition and the org- $\mathrm{C}$ quantity supplied by $\mathrm{SS}$ addition $(\mathrm{r}=0.84$; $\mathrm{p} \leq 0.001)$. Nevertheless, according to Islam \& Weil (2000) and Fernandes et al. (2005), high soil respiration indices might indicate an ecological disequilibrium or a high level of ecosystem productivity. Therefore, a more reliable interpretation by means of the metabolic quotient $\left(q \mathrm{CO}_{2}\right)$ is suggested, that is, the soil respiration rate per unit of microbial biomass.

A significant decrease in microbial activity (MBA) was observed in SS-treated than in MF plots, whereas no significant differences were observed among microbial biomass carbon values (Table 5). MBA and MBC were positively correlated $(r=0.53 ; p \leq 0.05)$, that is, the biomass activity was proportional to its mass quantity, but not related with basal respiration. These results suggested a possible stress caused by increases in soil heavy metal contents in SS-treated plots, or by higher soil acidity as observed by Melo (2006). Nevertheless, Cardoso \& Fortes Neto (2000) and Fernandes et al. (2005) observed MBC increase with increasing SS rates even at high heavy metal levels. Therefore, it was inferred that the MBA and $\mathrm{MBC}$ decrease observed in the this study might be attributed to the lower soil $\mathrm{pH}$ values found in SStreated plots (Table 3), which were below the values reported by those authors.

Besides, a significant increase in $q \mathrm{CO}_{2}$ was observed in the SS over the MF-treatment (Table 5). This metabolic quotient may be considered a potential environmental stress index, since high $q \mathrm{CO}_{2}$ values indicate a great energy demand of the microbial community for its maintenance, with consequent decrease of the microbial quotient (Qmic), which represents the efficiency of org- $\mathrm{C}$ conversion into biomass. According to Islam \& Weil (2000) and Fernandes et al. (2005), $q \mathrm{CO}_{2}$ is negatively correlated with soil quality, i.e., high $q \mathrm{CO}_{2}$ values indicate microbial community stress, disturbance or functional

Table 4. Soil micronutrient availability at the 0 $0.20 \mathrm{~m}$ depth layer, in plots treated with sewage sludge at rates of $20 \mathrm{t} \mathrm{ha}^{-1}(\mathrm{~L} 2), 10 \mathrm{t} \mathrm{ha}^{-1}(\mathrm{~L} 1)$ and mineral fertilizer (MF)

\begin{tabular}{lrrrrr}
\hline Treatment & B & \multicolumn{1}{c}{ Cu } & Fe & Mn & Zn \\
\cline { 2 - 3 } & & \multicolumn{5}{c}{$\mathrm{mg} \mathrm{dm}^{-3}$} \\
L2 & $0.57 \mathrm{~A}$ & $15.73 \mathrm{~A}$ & $83.75 \mathrm{~A}$ & $72.18 \mathrm{~A}$ & $23.50 \mathrm{~A}$ \\
L1 & $0.35 \mathrm{~B}$ & $12.38 \mathrm{~B}$ & $45.50 \mathrm{~B}$ & $80.75 \mathrm{~A}$ & $20.08 \mathrm{~A}$ \\
MF & $0.21 \mathrm{C}$ & $5.78 \mathrm{C}$ & $11.00 \mathrm{C}$ & $27.68 \mathrm{~B}$ & $1.40 \mathrm{~B}$ \\
CV $(\%$ & 11.26 & 9.54 & 20.53 & 29.35 & 14.95 \\
F test & 0.0001 & 0.0001 & 0.0001 & 0.0112 & 0.0001
\end{tabular}

Means followed by the same letters in the same column do not differ by Tukey test $(\mathrm{p}<0.05)$. 
Table 5. Basal respiration (BR), microbial activity (MBA), microbial biomass carbon (MBC), metabolic quotient $\left(q \mathrm{CO}_{2}\right)$, microbial quotient (Qmic), and soil enzyme activities of protease and dehydrogenase, at the $0-0.20 \mathrm{~m}$ depth layer, in plots treated with sewage sludge at rates of $20 \mathrm{t} \mathrm{ha}^{-1}$ (L2), $10 \mathrm{t} \mathrm{ha}^{-1}$ (L1) and mineral fertilizer (MF)

\begin{tabular}{|c|c|c|c|c|c|c|c|}
\hline Treatment & BR & MBA & MBC & $q \mathrm{CO}_{2}$ & Qmic & Protease & Dehydrogenase \\
\hline & \multicolumn{2}{|c|}{$-\mu \mathrm{g} \mathrm{CO}_{2} \mathrm{~g}^{-1}$ day $^{-1} \longleftarrow$} & $\mu \mathrm{g} \mathrm{g}^{-1} \mathrm{C}$ & $\mu \mathrm{g} \mathrm{CO}{ }_{2} \mu \mathrm{g}^{-1} \mathrm{C}$ day $^{-1}$ & $\mu \mathrm{g} \mathrm{CO}_{2} \mu \mathrm{g}^{-1} \mathrm{C}$ & $\mu \mathrm{g} \mathrm{H} \mathrm{g}^{-1}$ solo $\mathrm{h}^{-1}$ & $\mathrm{mg}$ of $\mathrm{H}$ \\
\hline & $50.15 \mathrm{~A}$ & $1.114 \mathrm{~B}$ & 56.79 & $0.89 \mathrm{~A}$ & $3.24 \mathrm{~B}$ & 0.85 & 1.63 \\
\hline $\mathrm{L} 1$ & $37.91 \mathrm{~B}$ & $1.288 \mathrm{~B}$ & 63.85 & $0.63 \mathrm{AB}$ & $4.01 \mathrm{~B}$ & 1.06 & 3.36 \\
\hline MF & $27.96 \mathrm{~B}$ & $1.623 \mathrm{~A}$ & 88.55 & $0.35 \mathrm{~B}$ & $7.10 \mathrm{~A}$ & 1.08 & 3.26 \\
\hline CV (\%) & 13.86 & 10.97 & 27.85 & 21.34 & 28.66 & 26.44 & 30.46 \\
\hline Teste F & 0.0033 & 0.0075 & 0.1283 & 0.0039 & 0.0161 & 0.4331 & 0.0462 \\
\hline
\end{tabular}

Means followed by the same letter in the same column do not differ by the Tukey test $(p<0.05)$.

disequilibrium. However, the $q \mathrm{CO}_{2}$ measured in the SS-L1 treatment (recommended SS dose based on maize $\mathrm{N}$ demand) did not significantly differ from the value found in the MF-treatment. In general, these values are similar to the results of Fernandes et al. (2005) in an experiment with increasing rates of SS from Barueri and Franca (cities in the State of São Paulo); and of Cardoso \& Fortes Neto (2000), who evaluated the effects of increasing SS soil applications (up to $160 \mathrm{t} \mathrm{ha}^{-1}$ ) on the soil microbiota, and reported increases in the metabolic quotient.

Therefore, a decreasing microbial quotient (Qmic) was observed as SS rates increased (L1, L2) compared to the MF-treatment (Table 5), corroborating the results of Melo (2006) in a eutroferric Red Oxisol. According to Tótola \& Chaer (2002), Qmic provides a measure of the soil organic matter quality; thus, the higher the Qmic value the higher the efficiency of soil org-C conversion into MBC (Melo, 2006). For the latter author, this relationship might be understood as an organic matter mineralization potential, and thus, the lower the relation between MBA and org-C, the lower the mineralization rate.

The $q \mathrm{CO}_{2}$ and $\mathrm{Qmic}$ values are coherent and highly negatively correlated $(r=-0.89 ; p \leq 0.0001)$, indicating a stress scenario with increasing energy demand for carbon metabolism concomitantly with decreasing soil organic matter quality. This means that SS applications produced unfavorable conditions for soil organic matter mineralization. In the plots treated with six annual SS applications (a total of $298 \mathrm{t} \mathrm{ha}^{-1}$ on a dry basis), soil org- $\mathrm{C}$ in the form of oils and greases was $11.9 \%$, compared to the $1.7 \%$ found in the MF plots, indicating that SS application induced accumulation of these substances considered recalcitrant (Hohla et al., 1978).

The protease activity has the function to catalyze the hydrolysis of protein- $\mathrm{N}$, giving rise to a mixture of amino acids which in turn decompose to ammonium$\mathrm{N}$ (ammonification reaction), available to plants and microorganisms (Karaca et al., 2002), or are oxidized to nitrate (nitrification reaction); no significant treatment effects were observed on the enzyme activity. These results disagree with those of Melo (2006), who reported increased protease activity in two Oxisols treated with increasing SS rates up to $60 \mathrm{t} \mathrm{ha}^{-1}$ (SS from Barueri, State of São Paulo).

The soil dehydrogenase activity reflects the total oxidative capacity of the microbiota, acting as an indicator of soil microbial activity (Andrade \& Silveira, 2004). No significant effect of SS-L1 on this enzyme activity was observed, but a $50 \%$ reduction was found in SS-L2 plots. This result contradicted Araújo et al. (2009), who observed increased soil enzyme activity with increasing SS rates (SS from Franca, State of São Paulo), probably due to the presence of toxic elements in the residue and also to a decrease in soil $\mathrm{pH}$, favoring the availability of heavy metals.

Positive correlations were found between soil dehydrogenase activity and $\operatorname{MBA}(r=0.53 ; p \leq 0.05)$ and Qmic ( $r=0.60 ; p \leq 0.04)$, but negative correlations were observed between this enzyme activity and $q \mathrm{CO}_{2}$ $(\mathrm{r}=-0.70 ; \mathrm{p} \leq 0.01)$, indicating again that SS application caused a stress condition to soil microbiota, mainly at the higher rate (L2).

The analytical results of the potentially toxic elements (PTE) indicated that none of these elements reached the intervention value for agricultural use established by CETESB (2005). The conclusion was drawn that the SS applied for seven years in this study resulted in no restrictions for agriculture with regard to heavy metal contents, even at the highest $\mathrm{SS}$ rate applied to maize (Table 6).

The maize grain yield in the 2008/2009 growing season was highest in the SS-L1 plots, followed by MF and L2-SS treatments (Figure 1). Maize shoot dry matter yield was higher in the SS-treatments. After seven years of successive SS applications, based on the maize $\mathrm{N}$ demand, the residue efficiently supplied maize $\mathrm{N}$ and $\mathrm{P}$ demands. 
Table 6. Soil total concentrations of potentially toxic elements, at 0-0.20 m depth layer, from SStreated plots (L1 and L2 sewage sludge rates) and MF-treated plots

\begin{tabular}{|c|c|c|c|}
\hline \multirow{2}{*}{ Element } & \multicolumn{3}{|c|}{ Guide value $^{(1)}$} \\
\hline & Reference & & Intervention \\
\hline Arsenium (mg kg') & 15 & & 35 \\
\hline Barium (mg kg') & 150 & & 300 \\
\hline Cadmium (mg kg $)$ & 1.3 & & 3 \\
\hline Lead $\left(\mathrm{mg} \mathrm{kg} \mathrm{g}^{-}\right)$ & 72 & & 180 \\
\hline Copper (mg kg) & 60 & & 200 \\
\hline Mercury (mg kg') & 0.5 & & 12 \\
\hline Nickel (mg kg') & 13 & & 30 \\
\hline \multirow[t]{3}{*}{ Zinc $(\mathrm{mg} \mathrm{kg})^{-1}$} & 300 & & 450 \\
\hline & \multicolumn{3}{|c|}{ Treatment } \\
\hline & MF & $\mathbf{L} 1$ & L2 \\
\hline Arsenium (mg kg') & 4.78 & 5.48 & 5.23 \\
\hline Barium (mg kg') & 14.88 & 30.33 & 38.63 \\
\hline Cadmium (mg kg) & 1.30 & 1.53 & 1.75 \\
\hline Lead (mg kg') & 14.13 & 18.65 & 23.23 \\
\hline Copper (mg kg') & 64.85 & 75.03 & 91.90 \\
\hline Mercury (mg kg') & 0.28 & 0.005 & 0.10 \\
\hline Nickel (mg kg $\left.{ }^{\prime}\right)$ & 9.68 & 10.20 & 11.03 \\
\hline Zinc $\left(\mathrm{mg} \mathrm{kg}^{\prime}\right)$ & 20.48 & 61.73 & 69.65 \\
\hline
\end{tabular}

(1) Guide values of quality reference and intervention for agriculture established by CETESB (2005). MF: mineral fertilizer; L1: $10 \mathrm{t} \mathrm{ha}^{-1}$ of sewage sludge (recommended dose to supply maize crop demand for N); L2: $20 \mathrm{t} \mathrm{ha}^{-1}$ of sewage sludge (twice the recommended dose).

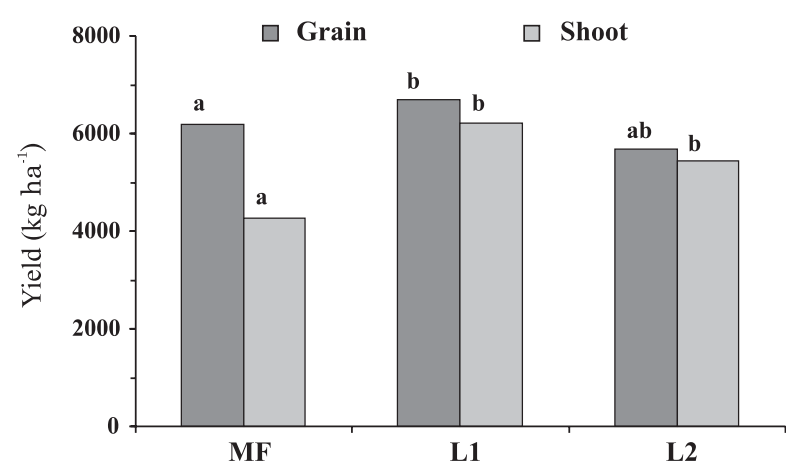

Figure 1. Maize shoot dry matter and grain yields, cultivated during summer 2008/2009, fertilized with mineral fertilizers (MF) and sewage sludge (SS) after seven successive applications of SS at the rates of $10 \mathrm{t} \mathrm{ha}^{-1}(\mathrm{~L} 1)$ and $20 \mathrm{t} \mathrm{ha}^{-1}(\mathrm{~L} 2)$. Means followed by the same letters within each variable do not differ by Tukey test $(p<0.05)$.

\section{CONCLUSIONS}

1. Sewage sludge applied to the soil at the recommended rates improved the availability of soil macro- and micronutrients, but some caution about Mg deficiency is advisable.
2. Sewage sludge applied at the recommended rates caused a negative effect on the soil microbial activity and biomass.

3 . Sewage sludge at the recommended rates was enough to maintain maize yields without the need for complementary fertilization with mineral N, P, and micronutrients fertilizers.

4. Seven successive annual sewage sludge applications based on the maize $\mathrm{N}$ demand raised the concentrations of potentially toxic elements in the soil to levels permitted by environmental regulatory laws.

\section{LITERATURE CITED}

ANDERSON, T.H. \& DOMSCH, K.H. Nitrifying of microbial biomass carbon in arable soils. Soils Biol. Biochem., 21:471479. 1989.

ANDRADE, S.A.L. \& SILVEIRA, A.P.D. Biomassa e atividade microbianas do solo sob influência de chumbo e da rizosfera da soja micorrizada. Pesq. Agropec. Bras., 39:1191-1198, 2004.

CASIDA L.E.; KLEIN, D.A. \& SANTORO, T. Soil dehydrogenase activity. Soil Sci., 98:371-376, 1964.

ARAÚJO, F.F.; GIL, F.C. \& TIRITAN, C.S. Lodo de esgoto na fertilidade do solo, na nutrição de Brachiaria decumbens e na atividade da desidrogenase. Pesq. Agropec. Trop., 39:1-6, 2009.

BARROW, N.J. Reaction of anions and cations with variablecharge soils. Adv. Agron., 38:183-230, 1985.

BERTON, R.S.; CAMARGO, O.A. \& VALADARES, J.M.A.S. Absorção de nutrientes pelo milho em resposta à adição de lodo de esgoto a cinco solos paulistas. R. Bras. Ci. Solo, 13:187-192, 1989 .

BERTON, R.S. \& PRATT, P.F. Evaluation of phosphorus requirement by the sorption isotherm technique in soils amended with organic materials. R. Bras. Ci. Solo, 21:199206, 1997.

BERTON, R.S.; VALADARES, J.M.A.S.; CAMARGO, O.A. \& BATAGLIA, O.C. Peletização do lodo de esgoto e adição de $\mathrm{CaCO}_{3}$ na produção de matéria seca e absorção de $\mathrm{Zn}$, $\mathrm{Cu}$ e Ni pelo aumento em três latossolos. R. Bras. Ci. Solo, 21:685-691, 1997.

BERTON, R.S. Riscos de contaminação do agroecossistema com metais pesados. In: BETTIOL, W. \& CAMARGO, O. A. Impacto Ambiental do Uso Agrícola do Lodo de Esgoto, Jaguariúna, SP: EMBRAPA Meio Ambiente, p.259, 2000.

BETTIOL, W. \& CAMARGO, O.A., ed. Lodo de esgoto: Impactos ambientais na agricultura. Jaguariuna, Embrapa Meio Ambiente, 2006. 349p.

CARDOSO, E.J.B.N. \& FORTES NETO, P. Aplicabilidade do biossólido em plantações florestais: III. Alterações microbianas no solo. In: BETTIOL, W. \& CAMARGO, O.A. Impacto ambiental do uso agrícola do lodo de esgoto. Jaguariúna, Embrapa Meio Ambiente, 2000. p.259. 
COMPANHIA DE TECNOLOGIA DE SANEAMENTO AMBIENTAL - CETESB. Manual Técnico P4.230: Aplicação de lodo de sistema de tratamento biológico em áreas agrícolas - Critérios para projeto e operação. São Paulo, 1999. 32p.

COMPANHIA DE TECNOLOGIA DE SANEAMENTO AMBIENTAL DO ESTADO DE SÃO PAULO - CETESB - Relatório de Estabelecimento de Valores Orientadores para Solos e Águas Subterrâneas no Estado de São Paulo. São Paulo, 2005

CHIBA, M.K.; MATTIAZZO, M.E. \& OLIVEIRA, F.C. Cultivo de cana-de-açúcar em Argissolo tratado com lodo de esgoto. II: Disponibilidade de nitrogênio no solo e componentes de produção. R. Bras. Ci. Solo, 32:653-662, 2008.

CHIBA, M.K; MATTIAZZO, M.E. \& OLIVEIRA, F.C. Rendimento de cana-de-açúcar cultivada em Argissolo, utilizando lodo de esgoto como fonte de fósforo. Acta Sci.Agron, 31:495-501, 2009.

DE MARIA, I.C.; CHIBA, M.K.; COSTA, A. \& BERTON, R.S. Sewage sludge application to agricultural land as soil physical conditioner. R. Bras. Ci. Solo, 34:967-974, 2010.

EMPRESA BRASILEIRA DE PESQUISA AGROPECUÁRIA EMBRAPA. Centro Nacional de Pesquisa de Solos. Sistema brasileiro de classificação de solos. 2.ed. Rio de Janeiro, 2006.306p.

FERNANDES, S.A.P.; BETTIOL, W. \& CERRI, C.C. Effect of sewage sludge on microbial biomass, basal respiration, metabolic quotient and soil enzymatic activity. Appl. Soil Ecol., 30:65-77, 2005.

GALDOS, M.V.; DE MARIA, I.C. \& CAMARGO, O.A. Atributos químicos e produção de milho em um Latossolo Vermelho eutroférrico tratado com lodo de esgoto. R. Bras. Ci. Solo, 28:569-577, 2004.

HOHLA, G.N.; JONES, R.L. \& HINESLY, T.D. The effect of anaerobically digested sewage sludge on organic fractions of Blount silt loam. J. Environ. Qual., 7:559-563, 1978.

ISLAM, K.R. \& WEIL, R.R. Land use effects on soil quality in a tropical forest ecosystem of Bangladesh. Agric. Ecosyst. Environ., 79:9-16, 2000

JORGE, J.A.; CAMARGO, O.A. \& VALADARES, J.M.A.S Condições físicas de um Latossolo Vermelho-Escuro, quatro anos após a aplicação de lodo de esgoto e calcário. R. Bras. Ci. Solo, 15:237-240, 1991.

KARACA, A.; NASEBY, D.C. \& LYNCH, J.M. Effect of cadmium contamination with sewage sludge and phosphate fertiliser amendments on soil enzyme activities, microbial structure and available cadmium. Biol. Fert. Soils, 35:428-434, 2002.

LADD, J.N. \& BUTLER, J.H.A. Short term assays of soil proteolytic enzyme activities using proteins and dipeptide derivatives as substrates. Soil Biol. Biochem., 4:19-32, 1972 .

MALAVOLTA, E. Manual de nutrição mineral de plantas Campinas, Ceres, 2006. p.631.
MELO, V.P.; BEUTLER, A.N.; SOUZA, Z.M.; CENTURION, J.F. \& MELO, W.J. Atributos físicos de Latossolos adubados durante cinco anos com biossólido. Pesq. Agropec. Bras., 39:67-72, 2004.

MELO, V.P. Carbono, nitrogênio e atividade biológica em Latossolos cultivados com milho, no sexto ano de aplicação de lodo de esgoto. Jaboticabal, Universidade Estadual de São Paulo, 2006. 93p. (Tese de Doutorado)

MELO, W.J.; MARQUES, M.O.; SANTIAGO, G.; CHELLI, R.A. \& LEITE, S.A.S. Efeito de doses crescentes de lodo de esgoto sobre frações da matéria orgânica e CTC de um Latossolo cultivado com cana-de-açúcar. R. Bras. Ci. Solo, 18:449-455, 1994.

MUNOZ HERNANDES, R.J. \& SILVEIRA, R.I. Efeitos da saturação por bases, relações Ca:Mg no solo e níveis de fósforo sobre a produção de material seco e nutrição mineral do milho (Zea mays L.). Sci. Agríc. 55:79-85, 1998.

NAGAJARAH, S.; POSNER, A.M. \& QUIRK, J.P. Competitive adsorption of phosphate with polygalacturonate and other organic anions on kaolinite and oxide surfaces. Nature, 228:83-85, 1970.

NOGUEIRA, T.A.R.; OLIVEIRA, L.R.; MELO, W.J; FONSECA, I.M.; MELO, G.M.P.; MELO, V.P. \& MARQUES, M.O. Cádmio, cromo, chumbo e zinco em plantas de milho e em latossolo após nove aplicações anuais de lodo de esgoto. R. Bras. Ci. Solo, 32:2195-2207, 2008.

OLIVEIRA, F.C. Disposição de lodo de esgoto e composto de lixo urbano num Latossolo Vermelho-Amarelo cultivado com cana-de-açúcar. Piracicaba, Escola Superior de Agricultura "Luiz de Queiroz", 2000. p.247. (Tese de Doutorado),

PRATT, P.F.; THORNE, M.D. \& WIERSMA, F. Future direction of waste utilization. In: ELLIOT, L.E. \& STEVENSON, F.J. Soils for management of organic wastes and waste waters. Madison, American Society of Agronomy, 1977. p.621-634.

RAIJ, B.van; ANDRADE, J.C.; CANTARELLA, H. \& QUAGGIO, J.A., eds. Análise química para avaliação da fertilidade de solos tropicais. Campinas, Instituto Agronômico de Campinas, 2001. 285p.

RAIJ, B.van; CANTARELLA, H.; QUAGGIO, J.A. \& FURLANI, A.M.C. Recomendações de adubação e calagem para o Estado de São Paulo. 2.ed. Campinas, Instituto Agronômico/Fundação IAC, 285p. 1996. (Boletim Técnico, 100)

SATTEL, R.R. \& MORRIS, R.A. Phosphorus fractions and availability in Sri Lankan Alfisols. Soil Sci. Soc. Am. J., 56:1510-1515, 1992.

SIMONETE, M.A.; KIEHL, J.C.; ANDRADE, C.A. \& TEIXEIRA, C.F.A. Efeito do lodo de esgoto em um Argissolo e no crescimento e nutrição de milho. Pesq. Agropec. Bras., 38:1187-1195, 2003.

SOUZA, D.M.G.; MIRANDA, L.N. \& OLIVEIRA, S.A. Acidez do solo e sua correção. In: NOVAIS, R.F.; ALVAREZ V, V.H.; BARROS, N.F.; FONTES, R.L.F.; CANTARUTTI, R.B. \& NEVES, J.C.L. Fertilidade do solo. Viçosa, MG, Sociedade Brasileira de Ciência do Solo, 2007. p.205-274. 
TÓTOLA, M.R. \& CHAER, G.M. Microrganismos e processos microbiológicos como indicadores da qualidade dos solos. In: ALVAREZ V., V. H.; SCHAEFER, C.E.G.R.; BARROS, N.F.; MELLO, J.W.V. \& COSTA, L.M. Tópicos em ciência do solo. Viçosa, MG, Sociedade Brasileira de Ciência do Solo, 2002. v.2. p.195-276.

VANCE, E.D.; BROOKES, P.C. \& JENKINSON, D.S. An extraction method for measuring soil microbial biomass C. Soil Biol. Biochem., 19:703-707, 1987.
WERF, H.van \& VERSTRATE, W. Estimation of active microbial biomass by mathematical analysis of respiration curves: Relation to conventional estimation of total biomass. Soil Biol. Biochem., 19:267-271, 1987. 